\title{
Staphylococcal scalded skin syndrome
}

\author{
C. G. GEMMELL
}

Department of Bacteriology, University of Glasgow Medical School, Glasgow Royal Infirmary, University NHS Trust, Glasgow G4 OSF

\begin{abstract}
Summary. Staphylococcal scalded skin syndrome (SSSS) is a recognised clinical entity that affects primarily the very young and, in rare cases, the very old or the immunocompromised. Koch's postulates have been fulfilled in that: (i) Staphylococcus aureus is isolated from every case; (ii) $S$. aureus can reproduce the syndrome in an experimental animal model; (iii) a specific extracellular toxin can reproduce the syndrome; and (iv) antibody to the toxin can protect experimental animals. Although exfoliative toxin (ET) is responsible for the skin loosening seen in SSSS, it does not account for all the symptoms of the disease. Purified ET does not cause erythema in either neonatal mice or man, and the lesions are not painful unless the loosened epidermis is removed. This suggests that other factors, e.g., $\delta$-haemolysin, are involved in the pathogenesis of this condition. Although much has been learned about the pathogenesis of the syndrome, we are still largely ignorant of the factors which govern host resistance to SSSS (i.e., intoxication by ET-producing strains of $S$. aureus). It is fortunate from the patient's point of view that the aetiological agent can be destroyed readily by the use of appropriate antibiotic therapy.
\end{abstract}

\section{History and discovery of the syndrome}

Staphylococcus aureus continues to be a pathogen of major importance and to evolve new pathogenic capabilities. This propensity is well illustrated in the syndrome known today as staphylococcal scalded skin syndrome (SSSS). The ability of $S$. aureus to survive and multiply on the skin surface demonstrates its capacity to adapt to a potentially noxious environment comprising various other commensal bacteria and host products of metabolism. Once established in the flora, and this can happen very early in life, S. aureus may colonise rapidly and spread over large areas of the skin surface. In 1956, Lyell ${ }^{1}$ described a clinical syndrome in which the skin looks and feels as though it has been scalded by hot water. The syndrome was named toxic epidermal necrolysis (TEN), and has been described in infants as Ritter's disease, ${ }^{2}$ and in young children $^{3}$ as staphylococcal TEN (fig. 1). It is very rare in adults. A sudden onset of widespread reddening of the skin is followed by loosening of large areas. Where the loosened skin peels off, a dark red, painful, glistening surface is exposed (fig. 2).

The original description of TEN in four adults ${ }^{1}$ was followed by multiple descriptions of the syndrome in children. ${ }^{411} S$. aureus could be isolated from any of

Received 14 Feb. 1995: accepted 22 March 1995. these patients, with most strains belonging to phage group II. It had been shown already that staphylococci belonging to this phage group were associated with impetigo, pemphigus neonatorum and the extremely rare Ritter's disease. ${ }^{12-17}$ In particular, phage group II strains are able to cause opacity on serum agar. Subsequently, Parker ${ }^{18}$ emphasised the correlation between a positive serum opacity reaction, a negative egg-yolk reaction, and the ability to give a sharply delineated zone of inhibition of Corynebacterium diphtheriae amongst impetiginous strains of $S$. aureus.

However, no attempt was made to differentiate strains of $S$. aureus isolated from cases of TEN or Ritter's disease from those isolated from impetigo contagiosa sensu stricto until Arbuthnott et al. ${ }^{19}$ compared 15 strains from TEN (group E) with 11 strains from impetigo (group L) for their ability to elaborate haemolysins and various exo-enzymes in vitro. Strains from groups $\mathrm{E}$ and $\mathrm{L}$ were generally similar in their patterns of proteolytic activity, low incidence of positive egg-yolk reaction, possession of lipase and production of hyaluronidase (table I). A subsequent study ${ }^{20}$ of lipolytic activity amongst these strains showed that the range of lipid substrates attacked by the lipase-esterase complex was greater amongst group $\mathrm{E}$ than amongst group $\mathrm{L}$ strains. In particular, lipids containing $\mathrm{C}_{16}$ and $\mathrm{C}_{18}$ saturated and unsaturated fatty acids were susceptible to attack by 


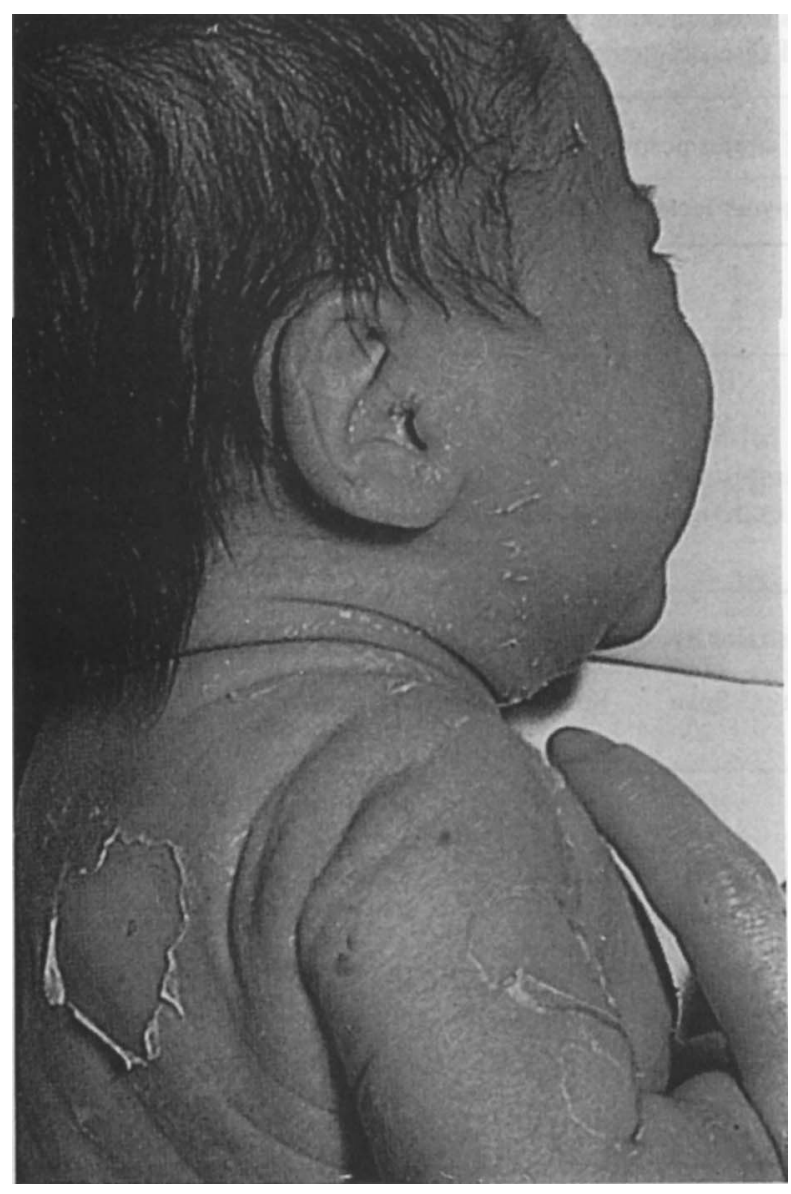

Fig. 1. SSSS in a baby-erythematous stage and early skin loosening (reproduced courtesy of Dr A. Lyeli).

group E strains (table II). In view of the much higher concentration of sebaceous glands in the skin of children compared to adults, an ecological advantage may be offered to certain strains of $S$. aureus by virtue of their ability to hydrolyse skin lipids released by these glands. ${ }^{21}$

Measurement of the haemolytic activity of the various isolates also revealed a higher than usual presence of $\delta$-haemolysin, as distinct from $\alpha$ haemolysin. ${ }^{19}$ Eight of $15 \mathrm{~S}$. aureus strains from group $\mathrm{E}$ produced this toxin, and in greater quantities, in vitro than all but one of the strains from group $L$. The knowledge that this toxin is dermonecrotic in mice at extremely low doses raised the possibility of its involvement in the pathogenesis of "scalding". However, the subsequent finding that epidermolytic toxin(s) ${ }^{22}$ or exfoliatin(s) (ET) ${ }^{23}$ are more likely virulence factors has limited our interest in other staphylococcal exoproducts as aggressins in SSSS.

\section{Clinical features, aetiology and epidemiology of the disease}

The disease originates from a focus of infection in which the producer organism, $S$. aureus, releases an exfoliative toxin (ET) (or epidermolytic toxin) that causes cleavage of the middle layers of the epidermis, bulla formation and, ultimately, slippage of the superficial layer of the epithelium on gentle pressure (a positive Nikolsky sign). Lyell ${ }^{24}$ described the clinical manifestations of epidermolytic toxin activity in different age groups and divided them into two groups, $\mathrm{A}$ and $\mathrm{B}$ (table III). The distinction between groups A and $B$ is usually clear-cut, but can occasionally be difficult, e.g., in confluent impetigo.

The aetiology of SSSS was established firmly when it was demonstrated that strains of $S$. aureus isolated from such patient groups could cause exfoliation in neonatal mice. ${ }^{25}$ This reaction was observed whether the staphylococci isolated were from cases exhibiting generalised exfoliation, bullous impetigo or only scarlatiniform rash. These manifestations of disease were assumed to represent the spectrum of clinical responses to infection with the same organism.

The generalised form of SSSS is generally associated

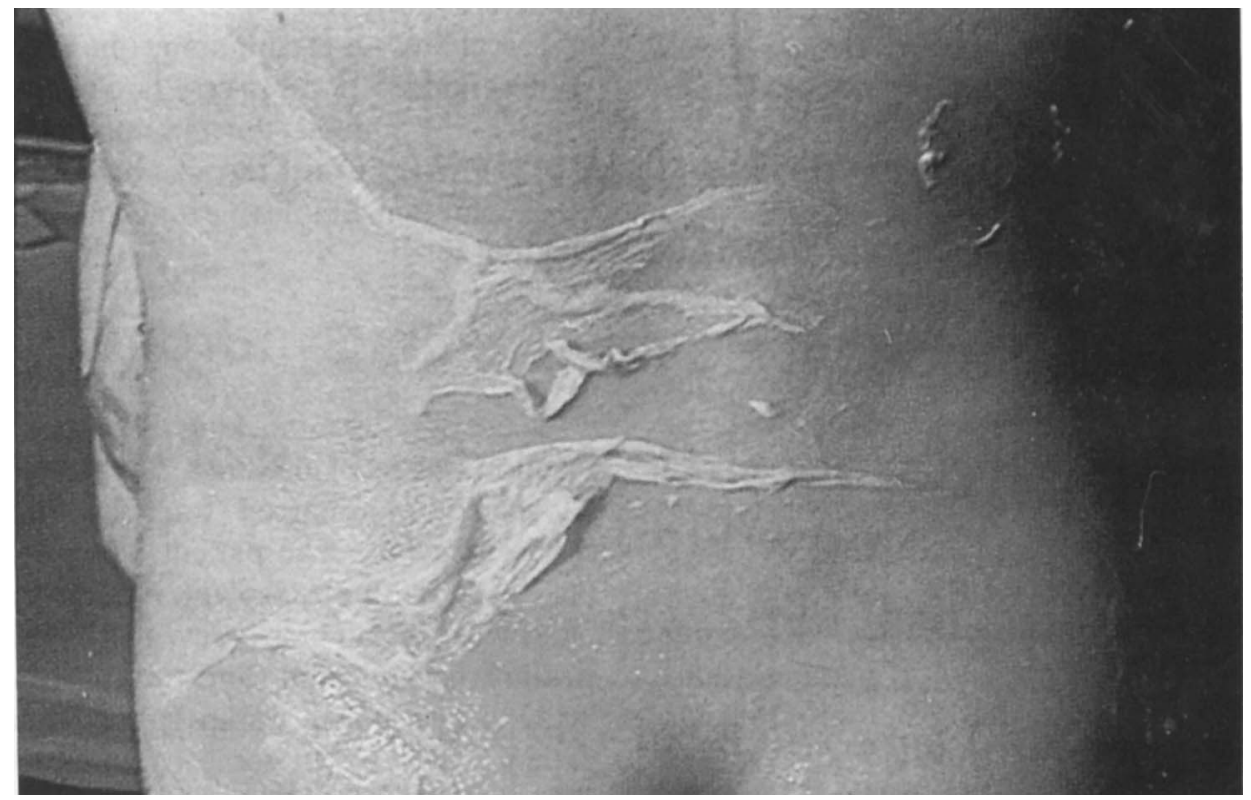

Fig. 2. Staphylococcal TEN, as defined by Lyell, ${ }^{24}$ showing extensive skin loosening (reproduced courtesy of Dr A. Lyell). 
Table I. Enzyme patterns of $S$. aureus strains isolated from TEN (extensive disease, group E) and impetigo contagiosa (localised disease, group L)

\begin{tabular}{lccccc}
\hline & \multicolumn{5}{c}{ Number of strains positive for } \\
\cline { 2 - 7 } Source (n) & Gelatinase & Fibrinolysin & Egg-yolk factor & Lipase & Hyaluronidase \\
\hline Group E (15) & 15 & 8 & 2 & 13 & $14^{*}$ \\
Group L (11) & 11 & 7 & 2 & 8 & 11 \\
\hline
\end{tabular}

*One strain not tested

Table II. Hydrolysis of Tween and Span compounds by $S$. aureus strains isolated from TEN (extensive disease, group E) and impetigo contagiosa (localised disease, group L)

\begin{tabular}{lccccccccc}
\hline & \multicolumn{7}{c}{ Percentage of strains hydrolysing } \\
\cline { 2 - 10 } Source & Tween & Tween & Tween & Tween & Span & Span & Span & Span \\
& 20 & 40 & 60 & 80 & 20 & 40 & 60 & 80 \\
\hline Group E & 66.6 & 80 & $93 \cdot 3$ & 20 & 100 & $53 \cdot 3$ & $13 \cdot 3$ & $46 \cdot 6$ \\
Group L & $81 \cdot 8$ & $81 \cdot 8$ & $45 \cdot 1$ & 0 & $90 \cdot 9$ & $45 \cdot 4$ & 0 & $36 \cdot 3$ \\
\hline
\end{tabular}

Table III. Clinical manifestations of epidemolytic toxin $\left(\right.$ Lyell $\left.^{24}\right)$

\begin{tabular}{cccc}
\hline Clinical & \multicolumn{3}{c}{ Clinical manifestation in } \\
\cline { 2 - 4 } group & Infants & Children & Adults \\
\hline A & $\begin{array}{c}\text { Pemphigus } \\
\text { neonatorum } \\
\text { Ritter's } \\
\text { disease }\end{array}$ & $\begin{array}{c}\text { Impetigo } \\
\text { (staph.) } \\
\text { Toxic epidermal } \\
\text { necrolysis (TEN) }\end{array}$ & $\begin{array}{c}\text { Impetigo } \\
\text { (staph.) } \\
\text { Adult TEN }\end{array}$ \\
\hline
\end{tabular}

with children aged $<10$ years. The syndrome has been recognised in only a handful of cases in adults. ${ }^{26}$ Of these, underlying malignancy together with immunosuppressive therapy, rheumatic heart disease, diabetes mellitus or heroin addiction were recognised as predisposing conditions. Significant bacteraemia appears to be crucial in the development of SSSS in adults without underlying immunocompromise. It is now recognised that the condition is more common in children, where it occurs in previously healthy individuals, has a low mortality rate $(3 \%$ with appropriate antibiotic therapy), and is usually associated with a trivial infective focus in the conjunctivae or skin. In contrast, in adults the disease is uncommon, the mortality rate is $>50 \%$ despite antibiotics, and the initiating infection is likely to be bacteraemia with additional involvement of some degree of host immunocompromise.

In order for knowledge of the ETs and their elaboration by strains of $S$. aureus to help in our understanding of the different clinical manifestations of staphylococcal infection, the host response must also be considered. Normally, impetigo is recognised as pemphigus neonatorum or staphylococcal impetigo contagiosa, and scalding as Ritter's disease or staphyl-
Table IV. Published reports of SSSS in adults

\begin{tabular}{|c|c|c|}
\hline Case report & $\begin{array}{c}\text { Number } \\
\text { of } \\
\text { cases }\end{array}$ & Underlying disease \\
\hline Lyell $^{1}$ & 4 & Various \\
\hline$O^{\prime}$ Keefe et al. ${ }^{28}$ & 2 & Age $>80$ years \\
\hline Opal et al. ${ }^{29}$ & 2 & None \\
\hline Goldberg et al ${ }^{30}$ & 1 & Chronic myeloid leukaemia \\
\hline Richard \& Mathieu-Serra ${ }^{31}$ & 1 & Homosexual, AIDS \\
\hline Alcalay et $a l^{32}$ & 1 & Age $>65$ years \\
\hline Takiuchi et al. ${ }^{33}$ & 1 & Not given \\
\hline Petzelbauer et al. ${ }^{34}$ & 2 & Acute kidney failure \\
\hline Saiag et al. ${ }^{35}$ & 2 & Not given \\
\hline
\end{tabular}

ococcal TEN. It is likely that the age of the host predetermines, at least in some cases, whether impetigo and scalding are commoner in children than in adults-indeed, SSSS is very rare in adults and is seen usually only amongst the immunocompromised (table IV). ${ }^{23-35}$ With regard to race, it has been stated that black children are less prone to SSSS than white children. ${ }^{27}$

\section{SSSS in adults}

A case of SSSS mimicking an acute graft versus host reaction was recognised in a 33-year-old man after an allogeneic bone marrow transplant for chronic myeloid leukaemia. The patient developed a necrolytic rash 90 days after transplant. A diagnosis of SSSS was made when a skin biopsy revealed a typical split in the stratum granulosum and a strain of $S$. aureus belonging to phage group II was isolated from the patient's blood ${ }^{30}$ In some patients, the use of nonsteroidal anti-inflammatory drugs may predispose to SSSS. ${ }^{36}$ 
Table V. Serotypes of ET produced by $S$. aureus strains causing skin blistering conditions in the UK and Ireland

\begin{tabular}{lcc}
\hline \multirow{2}{*}{ Toxin serotype } & \multicolumn{2}{c}{ Number of strains (\%) of each ET serotype } \\
\cline { 2 - 3 } & Phage group II & Non-phage group II \\
\hline ETA & $31(36 \cdot 9)$ & $6(18 \cdot 7)$ \\
ETB & $13(15 \cdot 5)$ & $1(3 \cdot 1)$ \\
ETA + ETB & $28(33 \cdot 3)$ & $3(9 \cdot 4)$ \\
None & $12(14 \cdot 3)$ & $22(68 \cdot 8)$ \\
Total no. of & 84 & 32 \\
strains tested & & \\
\hline
\end{tabular}

Modified from de Azevedo and Arbuthnott. ${ }^{40}$

It has also been recognised that SSSS can occur in adults with no underlying disease or predisposing risk factors. ${ }^{29}$ In one case a phage group II strain was isolated, while a second case involved a group I/III strain. Both strains produced exfoliatin B (ETB), and a 23-kb plasmid with identical restriction endonuclease digestion fragments was identified in each strain. Such rare strains may be of greater importance than exfoliatin A (ETA)-producers in immunocompetent adults.

Patients with renal disease (decreased glomerular filtration and associated uraemic immunodeficiency) are predisposed to SSSS ${ }^{34}$ Children with this disease develop the adult form of SSSS, with $S$. aureus bacteraemia an important feature, rather than the superficial skin disease usually seen in children. ${ }^{37}$ One other group at risk of SSSS includes those patients with AIDS-related complex. ${ }^{31}$ For example, a 28 -yearold woman seropositive for HIV and undergoing haemodialysis for end-stage renal disease developed SSSS following infection of her arteriovenous graft. ${ }^{38}$ Reduction in the $T$ helper: $T$ suppressor ratio in such patients, together with anergy and lymphopaenia, may be relevant in this situation. Again, staphylococcal bacteraemia was a significant feature.

\section{Epidemiology}

Epidemiological data on $S$. aureus strains producing ET are scarce. In a prospective clinical and bacteriological study, ${ }^{39} 944 \mathrm{~S}$. aureus isolates from 577 dermatological patients were screened for ET production with the neonatal mouse model. Strains were differentiated as producing one of two types of ET-either ETA or ETB-by immunodiffusion. In total, $5.1 \%$ of the $S$. aureus isolates were identified as ET producers, of which $98 \%$ produced ETA. ETproducing strains could be isolated from patients in all age groups, although more often in those aged $<20$ years. A clinical picture of SSSS was seen in $32 \%$ of patients carrying ET-producing $S$. aureus. The remainder were suffering from skin conditions such as tinea, bullous dermatitis, atopic dermatitis, contact dermatitis and focal infections. Interestingly, $66 \%$ of patients carrying ET-producers also harboured nontoxinogenic strains of $S$. aureus. Epidemiologically, it
Table VI. Serotypes of ET produced by $S$. aureus strains causing impetigo and SSSS in Japan

\begin{tabular}{lcc}
\hline \multirow{2}{*}{ Toxin serotype } & \multicolumn{2}{c}{ Number of strains (\%) of each ET serotype } \\
\cline { 2 - 3 } & Phage group II & Non-phage group II \\
\hline ETA & $9(37 \cdot 3)$ & $0(0)$ \\
ETB & $0(0)$ & $15(78 \cdot 9)$ \\
ETA + ETB & $14(58 \cdot 3)$ & $2(10 \cdot 5)$ \\
None & $1(4 \cdot 2)$ & $2(10 \cdot 5)$ \\
Total no. of & 24 & 19 \\
strains tested & & \\
& &
\end{tabular}

Modified from Kondo et al. ${ }^{41}$

can be concluded that the carriage of ET-producing strains of $S$. aureus in patients not showing SSSS but with other dermatological conditions may be important.

It has also been shown that there are geographic differences in the incidence of strains producing ETA, ETB, both ETA and ETB, or no exfoliation. ${ }^{40.41}$ Production of ETA alone, or ETA plus ETB, is associated strongly with phage group II staphylococci in the UK and Ireland, ${ }^{40}$ whereas there appears to be some association between ETB production and nonphage group II strains in $\mathrm{Japan}^{41}$ (tables V and VI).

Nursery outbreaks of SSSS are usually caused by a single toxin-producing strain of $S$. aureus and may involve many infants. ${ }^{42}$ The strain is usually of phage group II, but strains of different phage groups have also been implicated. However, one outbreak in a maternity hospital was shown to take place in three phases in which two distinct tetracycline-resistant strains producing different ETs were involved.$^{43}$ In the first phase, the daytime staff of the delivery unit were implicated and eczematous skin conditions in midwives were the probable source. In the second phase, a source within a postnatal ward was suggested, with subsequent local cross-infection. In the final phase, both sources were linked epidemiologically to cases of SSSS. Thirty babies were involved-all 11 in phase I yielded ETB-producing $S$. aureus, 10 in phase II yielded ETA-producing $S$. aureus, and seven produced ETB and two produced ETA in phase III. Differences in plasmid content were also observed.

\section{Discovery, isolation and properties of ET (epidermolytic toxin)}

The toxin responsible for the skin changes is an exotoxin elaborated by the staphylococci only during the logarithmic phase of growth. There appear to be two forms of the toxin-designated ETA and ETB $^{44}$ - which differ in their antigenic specificity and heat stability. Many strains of $S$. aureus produce both toxins simultaneously. Control of synthesis of ETA is encoded by the bacterial chromosome, whereas ETB is encoded by a plasmid. Both genes have been sequenced ${ }^{45,46}$ and the ETA gene has been cloned in 
Table VII. Properties of staphylococcal ETs

\begin{tabular}{lll}
\hline & \multicolumn{2}{c}{ Toxin } \\
\cline { 2 - 3 } Property & ETA & ETB \\
\hline Mol. wt & 30000 & 29500 \\
Iso-electric point & 7.0 & 6.9 \\
Heat sensitivity & Stable & Labile \\
Genetic control & Chromosomal & Plasmid \\
\hline
\end{tabular}

Escherichia coli. ${ }^{47}$ The toxins also differ in mol. wt as well as immunologically (see table VII), with the plasmid-encoded toxin having the lower mol. wt. ${ }^{48}$ Furthermore, it was found that these toxins were elaborated by phage group I and III strains of $S$. aureus as well as the hitherto well-recognised group II strains. $^{19}$ The toxin appears to act purely extracellularly, separating cells from the stratum granulosum and stratum spinosus cells with the epidermis. ${ }^{50}$ Splitting of the desmosomes produces a cleavage plane which results in exfoliation. ${ }^{51}$ No effect is seen on nearby basal cells (figs. 3 and 4). Toxaemia can be demonstrated in patients with generalised SSSS, ${ }^{52}$ but only at the limits of serological detection $(1-5 \mu \mathrm{g} / \mathrm{ml}$ of serum).

Beneath and attached to the desmosome lies a condensation of filaments which help maintain the cytoskeleton by forming a framework within the cell. The toxin binds to the filaggrin group of proteins ${ }^{52}$ which support these filaments. The mechanism of epidermolysis is unknown, although it is assumed that intercellular cohesive forces, mostly generated by desmosomes, are disrupted. It had been postulated that ETA and ETB might themselves be, or be inducers of, proteolytic enzymes ${ }^{52}$ causing desmosome disruption. ${ }^{51}$ However, addition of protease inhibitors to both in-vitro and in-vivo models of epidermolysis failed to inhibit epidermal splitting ${ }^{50,53-55}$ and, until the demonstration of similarities between ET and serine protease (see below), it was agreed generally that ET had no proteolytic activity.

The nucleotide sequences of ETA and ETB have been established by three groups of workers. ${ }^{56-58}$ No evidence of a homologous relationship between the toxins and any other proteins was noted by these workers, but it was found subsequently that the aminoacid sequences of ETA and ETB have a marked resemblance to that of the proteinase of $S$. aureus strain V8, with c. $25 \%$ identity between ETA and the serine proteinase. ${ }^{59}$ In addition, it has been shown that both ETA and serine proteinase bind to di-isopropyl phosphorofluoridate. ${ }^{59}$ With serine proteinase, this binding takes place at serine-169, while with ETA it occurs at serine-195. Such information would suggest a functional relationship, ${ }^{60}$ but it is now well established that ETA has no proteolytic activity. ${ }^{55}$ Substitution of the serine-195 residue by a cysteine residue led to a biologically inactive protein. ${ }^{61} \mathrm{~A}$ potential $\mathrm{Ca}^{2+}$-binding loop was identified on the basis of sequence similarity with the second $\mathrm{Ca}^{2+}$-binding loop of rat intestinal calcium binding protein. Epid-

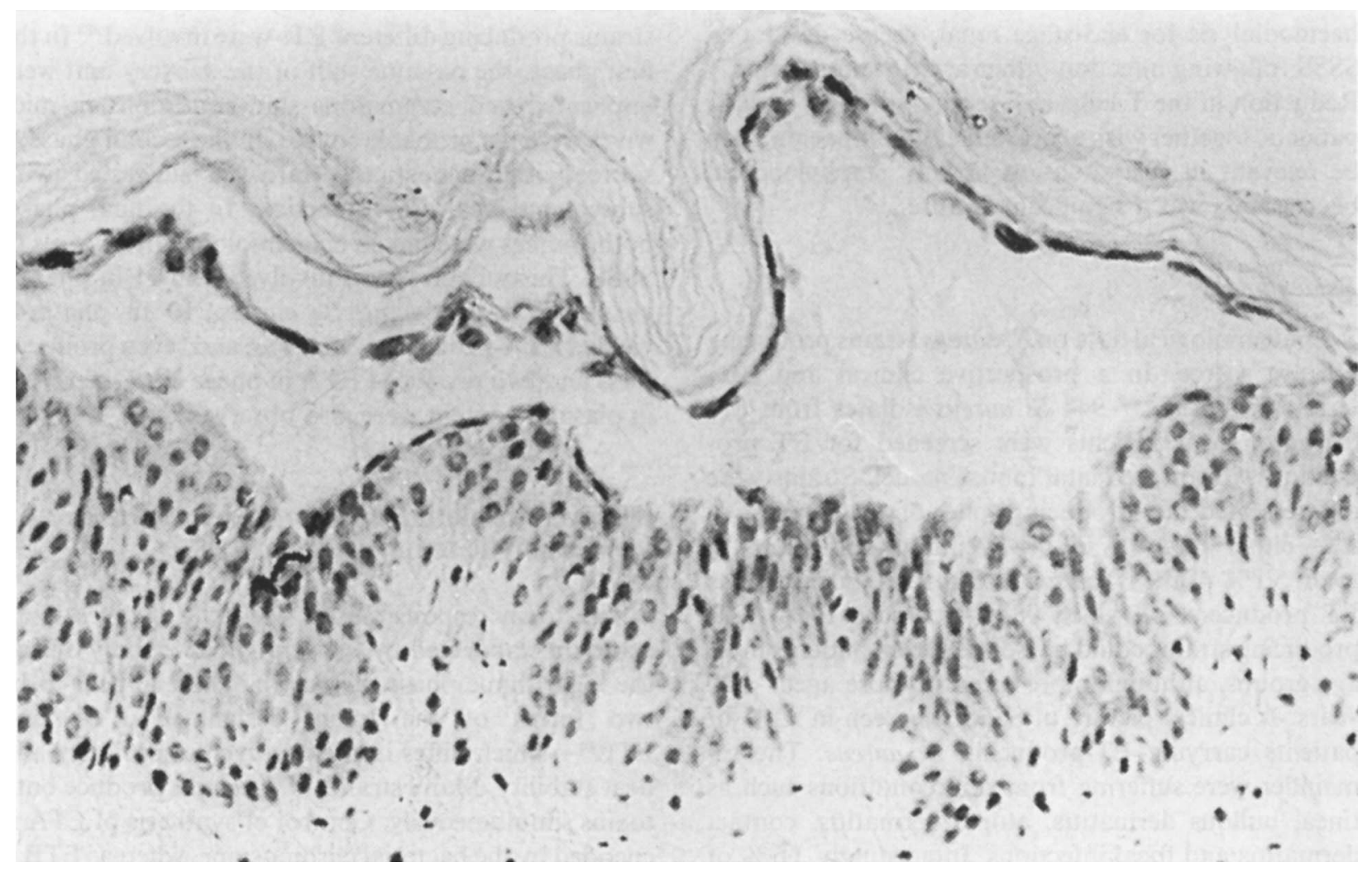

Fig. 3. Histological section of biopsy material from a case of SSSS showing the characteristic sub-corneal splitting (reproduced courtesy of Professor J. P. Arbuthnott). 


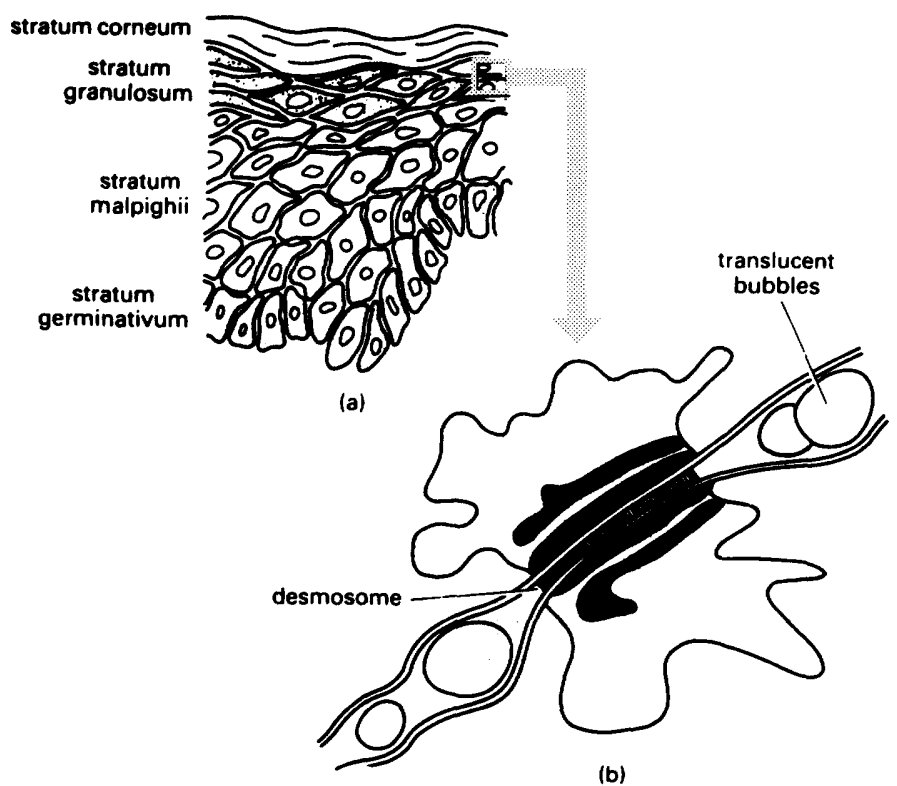

Fig. 4. Site of action of ET between the cells of the stratum granulosum. The toxin appears to cause splitting of the desmosomes, with the production ultimately of a large cleft between the cell layers as seen in fig. 3. Reproduced by permission from Pediatrics. ${ }^{51}$

ermolysis caused by ETA in the mouse bioassay was shown to be inhibited by the presence of EDTA, i.e., consistent with a $\mathrm{Ca}^{2+}$-dependent mechanism. ${ }^{62}$ Epidermolysis occurred without any change in rate through the $\mathrm{pH}$ range $3 \cdot 8-8 \cdot 7$, and at an increasing rate in the temperature range $0-37^{\circ} \mathrm{C}$. Even in the presence of inhibitors of energy metabolism, central metabolic pathways, receptor binding ${ }^{63}$ or proteolysis, epidermolysis was not prevented, and Smith and Bailey ${ }^{62}$ suggested that intoxication cannot depend on receptormediated endocytosis.

The search for the cellular receptor of ET was described by Kondo and Sakurai, ${ }^{64}$ who showed that a substance could be extracted from emulsified skin tissue of new-born mice with SDS $1 \% \mathrm{w} / \mathrm{v}$. The extract was able to inactivate ET after incubation at $37^{\circ} \mathrm{C}$ for $\leqslant 3 \mathrm{~h}$. In contrast, the same fraction from adult mice showed only very weak toxin inactivation. The ability of the SDS extract to neutralise or combine with ET was not lost with trypsin, pronase or heattreatment at $100^{\circ} \mathrm{C}$, suggesting that the complexing agent is not a protein. On the basis of earlier knowledge that certain gangliosides can act as receptors for bacterial toxins (e.g., cholera toxin or tetanus toxin), the same authors used bovine brain gangliosides in their studies with ET and found that mixtures of ET with $\mathrm{GM}_{1}$ ganglioside failed to elicit a positive Nikolsky sign following injection into neonatal mice. However, the presence of this ganglioside in neonatal mouse skin has not been described.

Both ETA and ETB are now recognised as belonging to the group of bacterial exoproducts-known as superantigens ${ }^{65}$ - which are capable of stimulating $\mathrm{T}$ lymphocytes by a mechanism quite distinct from that induced by conventional antigens. ${ }^{66}$

A conventional antigen is normally processed initially by an antigen-presenting cell, such as a macrophage, which then presents the antigen at the cell surface within a groove of the MHC class II molecule. This complex is recognised by a small number $\left(1\right.$ in $\left.c .10^{6}\right)$ of $T$ cells which bear specific receptors for this antigen. This highly specific interaction involves the variable joining and diversity positions of both the $\alpha$ and $\beta$ chains of the T-cell receptor.

In contrast, superantigens are able to stimulate a vast number of $\mathrm{T}$ cells by directly binding class II molecules of the antigen-presenting cells to the T-cell receptor. This interaction is restricted only by the specificity of the variable portion of the $\beta(\mathrm{V} \beta)$ chain. Any given superantigen stimulates a specific set of $\mathrm{V} \beta$ families, and since there are only about $20 \mathrm{~V} \beta$ families, a superantigen is capable of stimulating, per se, c. $5 \%$ of all $\mathrm{T}$ cells. The resultant excessive activation of cytokines, complement and clotting cascades, plus the production of free oxygen radicals and nitric oxide, may contribute to disease syndromes in which a superantigen is elaborated by the aetiological agent. Unlike another staphylococcal disease syndrome, toxic shock, the involvement of T-cell activation by a superantigen has not been investigated.

\section{Genetic control of ET biosynthesis}

Initial studies, ${ }^{67}$ involving growth at elevated temperatures in the presence of ethidium bromide, caused the loss of ET production by $S$. aureus, thereby implicating a plasmid. Moreover, a plasmid band at $56 \mathrm{~S}$ after sucrose density gradient centrifugation correlated with ET and bacteriocin markers in toxinogenic strains. However, in some toxin-producing strains, the capacity to form ET could not be eliminated completely by ethidium bromide curing. This suggested a possible chromosomal involvement in the control of 
Table VIII. Influence of age on the prevalence of antibody to ETA

\begin{tabular}{|c|c|c|}
\hline $\begin{array}{c}\text { Age of } \\
\text { individual (years) }\end{array}$ & $\begin{array}{l}\text { Number } \\
\text { tested }\end{array}$ & $\begin{array}{c}\text { Number }(\%) \text { of individuals } \\
\text { with ETA antibody }\end{array}$ \\
\hline At birth & 21 & $18(88)$ \\
\hline $0 \cdot 25-2$ & 47 & $14(30)$ \\
\hline $2-5$ & 57 & $30(42)$ \\
\hline $5-10$ & 34 & $17(50)$ \\
\hline $10-20$ & 13 & $10(77)$ \\
\hline $20-40$ & 88 & $72(82)$ \\
\hline $40-70$ & 23 & $21(91)$ \\
\hline
\end{tabular}

ET biosynthesis. ${ }^{48}$ Later studies showed that control of synthesis of serologically distinct forms of ET (ETA and ETB) was encoded by the chromosome and a plasmid, respectively. It is now clear that a $42-\mathrm{kb}$ plasmid is associated with ETB production, and restriction endonuclease analysis of this plasmid from several ET-producing strains has revealed similarities. ${ }^{68}$

\section{Antibody response to ET}

Radioimmunoassay (RIA) has been used to measure the prevalence of antibodies directed specifically against ETA in normal individuals and those with SSSS ${ }^{69}$ Evidence suggesting the presence of antibody was found in $88 \%$ of infant cord blood samples; thereafter, the level fell with increasing age until the age of 2 years (table VIII). A progressive increase in the presence of antibody with age followed.

Patients with SSSS do not exhibit specific antibody during the acute phase of illness, but do so during convalescence. Similar results obtained by RIA have been reported by others. ${ }^{44.70 .71}$ In contrast, patients with bullous impetigo possess circulating antibody throughout the infection. This is in character with the more localised nature of the infection, with the toxin being secreted locally by the staphylococci and acting in the immediate environs and not systemically, ${ }^{69}$ as in SSSS. Evidence for circulating free and antibodybound ET $(0 \cdot 3-8.4 \mathrm{mg} / \mathrm{ml})$ has also been found in patients with SSSS.

Rabbits are not susceptible to either ETA or ETB, but can produce antibodies to both toxins. Apart from man, neonatal mice are susceptible, but a conventional outbred mouse strain (ICR) or an inbred hairless mouse strain (HRS/J) were unable to produce high levels of antibody. However, when some inbred and congenic resistant strains with the defined histocompatibility complex (H-2 complex) were immunised with ETA, they could be classified into high and low responder groups. In a series of experimental immunisations, ${ }^{72}$ mouse strains belonging to $\mathrm{H}-2$ haplotypes, a, d, k and s were high responders, while $\mathbf{H}-2$ haplotypes $b$ and $q$ were low responders. Furthermore, breeding experiments between a high-responder strain and a low-responder strain produced offspring whose phenotypes of high response to ETA were assorted
Table IX. Effect of ETA immunisation on exfoliation in high- and low-responder mouse groups

\begin{tabular}{llc}
\hline $\begin{array}{l}\text { Mouse } \\
\text { strain used }\end{array}$ & Treatment & $\begin{array}{c}\text { Dose of ETA } \\
\text { causing exfoliation }\end{array}$ \\
\hline High-responder & Immunised with ETA & $8 \mu \mathrm{g}$ \\
& No immunisation & $0.8 \mu \mathrm{g}$ \\
Low-responder & Immunised with ETA & $0.8 \mu \mathrm{g}$ \\
& No immunisation & $0.8 \mu \mathrm{g}$ \\
\hline
\end{tabular}

according to Mendelian principles. It was concluded that a single autosomal dominant gene within the $\mathrm{H}-2$ complex controlled the production of antibody to ETA.

In contrast, mouse susceptibility to ETA was not related to their $\mathrm{H}-2$ complexes. The granular layer in the skin of neonatal mice was the target of ET, ${ }^{25,51,73}$ with doses of ET as low as $0.38 \mu \mathrm{g}$ showing activity. ${ }^{74}$ Immunisation of high-responders with ETA produced neonates resistant to $2.4 \mu \mathrm{g}$ of ETA, but not $8 \mu \mathrm{g}$ of ETA (table IX). Although the specific tissue location of the maternal antibody to ETA transferred to the newborn mouse was not identified, it is assumed that the placentally-transferred antibody has toxinneutralising activity.

\section{Experimental models of SSSS}

Newborn mice (i.e., $<5$ days old) are more susceptible to infection with $S$. aureus than older mice. Melish and Glasgow ${ }^{23}$ noted that phage group II isolates from both extensive and localised lesions produced a uniform response in newborn mice (fig. 5). Subcutaneous or intraperitoneal injection of viable bacteria resulted in extensive splitting of the epidermis that resembled TEN in man.

Employing the same neonatal mouse model, the existence of a diffusible factor (epidermolytic toxin; ET) in culture filtrates of a phage type II $S$. aureus strain isolated from a case of TEN was demonstrated. ${ }^{75}$ Subsequently, the same authors ${ }^{76}$ purified this toxin and showed that the purified product also displayed biological activity in the neonatal mouse model (fig. 6). No skin changes occurred in $>7$ day old mice. The response was dose-dependent, with animals infected intraperitoneally with either $10^{8}$ or $10^{7}$ viable staphylococci displaying a similar clinical course with the development of a positive Nikolsky sign-i.e., peeling of the epidermis following slight rubbing of the skin-12 and $16 \mathrm{~h}$ after infection. For these animals, ET was first detected in the blood after only $2 \mathrm{~h}$ and reached a peak $(14000 \mu \mathrm{g} / \mathrm{ml}) 6 \mathrm{~h}$ later. In contrast, animals inoculated with $10^{6}$ and $10^{5}$ bacteria did not become ill and no ET was found in the animals' blood after $8 \mathrm{~h}$, although $224 \mu \mathrm{g} / \mathrm{ml}$ was detected after $20 \mathrm{~h} .{ }^{70}$ However, older mice proved to be much more resistant to infection by staphylococci.

The factor described as "exfoliatin", isolated by 


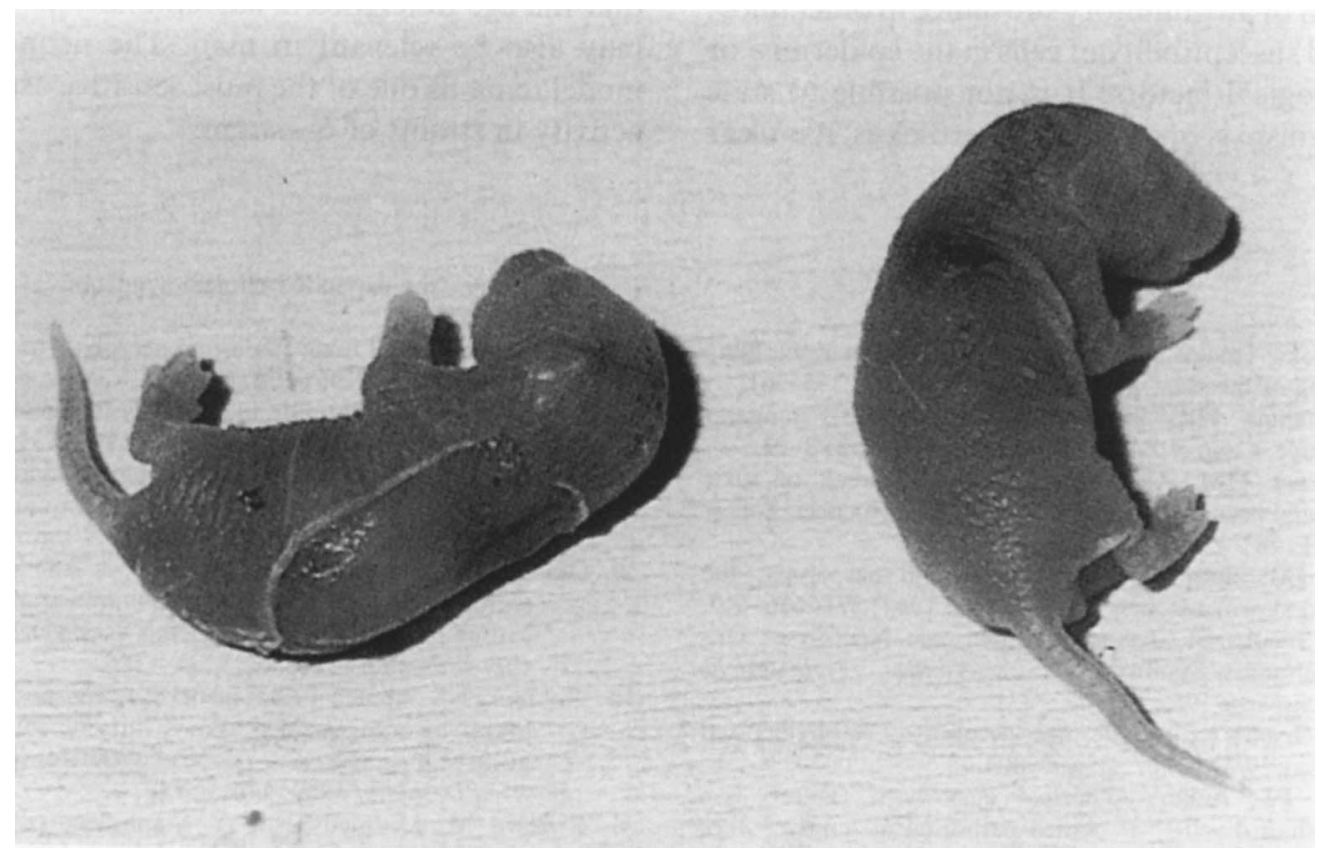

Fig. 5. SSSS in a newborn mouse (reproduced courtesy of Professor J. P. Arbuthnott).

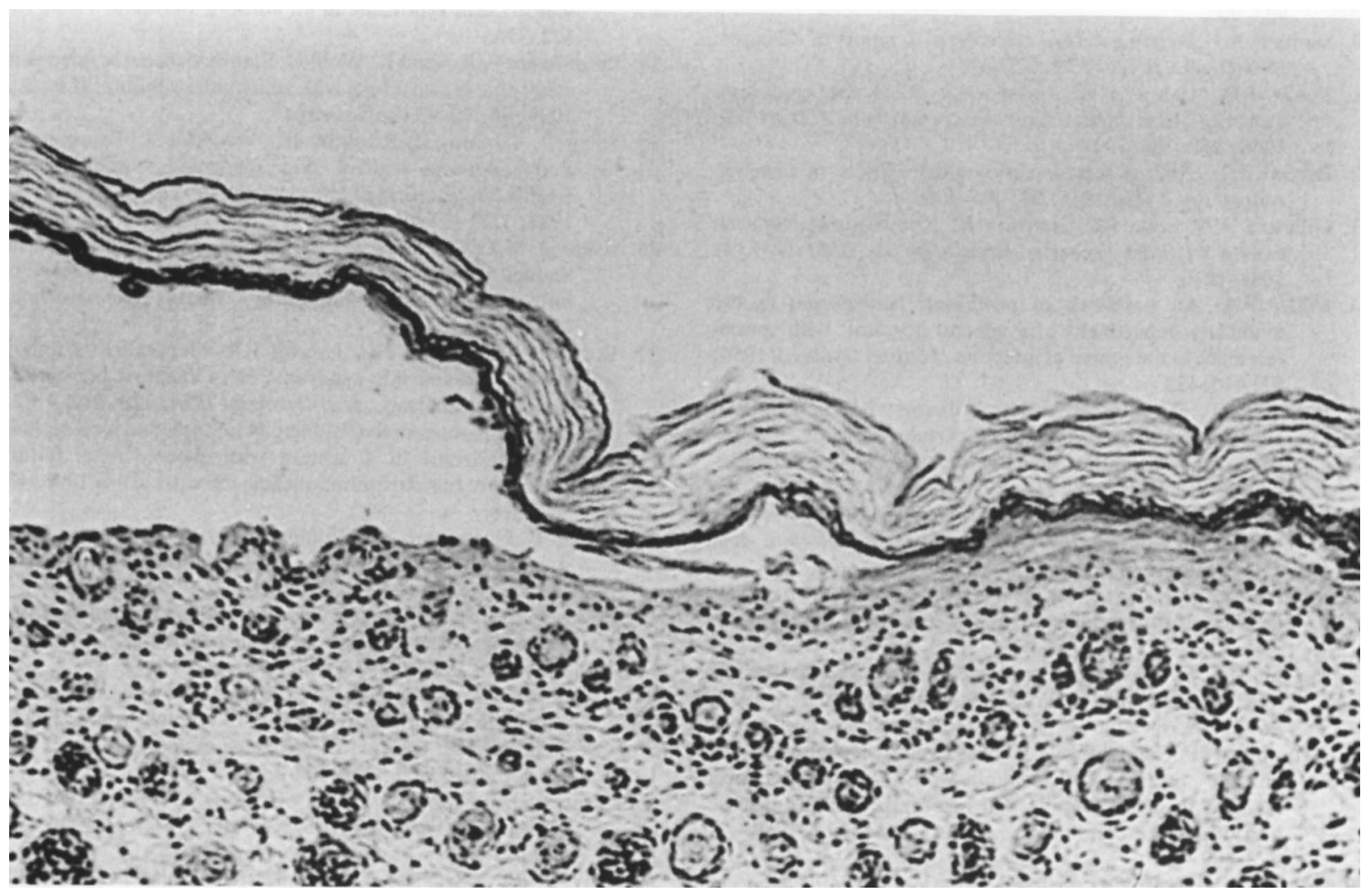

Fig. 6. Histological section of the skin of a newborn mouse inoculated with staphylococcal ET (reproduced courtesy of Professor J.P. Arbuthnott).

Kapral and Miller, ${ }^{77}$ also displayed biological activity in mouse epidermis. Both toxins caused intense reddening of the skin within $2 \mathrm{~h}$, extensive loosening of the skin at $4-5 \mathrm{~h}$, and death after 5-8 h. Histological examination revealed splitting of the epidermis similar to that obtained with viable organisms. The minimum effective dose of lyophilised culture filtrate was $200 \mu \mathrm{g}$, and the response was age dependent. Two-day-old mice were more sensitive than 6-day-old mice. The development of resistance to ET may be caused by: (a) 
the formation of an inhibitory substance in older mice; (b) an altered susceptibility of cells in the epidermis; or (c) immunological factors. It is not possible to state which mechanism is operating. Nevertheless, it is clear

\section{References}

1. Lyell A. Toxic epidermal necrolysis: an eruption resembling scalding of the skin. Br J Dermatol 1956; 68: 355-361

2. Von Rittershain GR. Die exfoliative dermatitis jungerer Sanglinge. Central Zeitung Kinderheilk $1878 ; 2: 3-23$.

3. Lyell A. Dick HM, Alexander J O'D. Outbreak of toxic epidermal necrolysis associated with staphylococci. Lancet $1969: 1: 787 \div 790$

4. Freedberg IM. Berg RB. Toxic epidermal necrolysis: the scalded-skin syndrome. N Engl J Med 1964: 271 : 616-617.

5. Holzel A, Jacobs SI. Toxische Epidermale Necrolyse: Das Verbruhungs-Syndrom. Sweizerische Medizinische Wochenschrifi 1966; 96: 427-431.

6. Jefferson $\mathbf{J}$. Lyell's toxic epidermal necrolysis: a staphylococcal aetiology? BMJ 1967: 2: 802-804

7. Koblenzer PJ. Acute epidermal necrolysis (Ritter von Rittershain-Lyell): a clinico-pathological study. Arch Dermatol 1967; 95: 608-617.

8. Lowney ED, Baublis JV, Kreye GM, Harrell ER, McKenzie AR. The scalded skin syndrome in small children. Arch Dermatol 1967: 95 : 359-369.

9. Potter B. Auerbach R, Lorincz AL. Toxic epidermal necrolysis acute pemphigus. Arch Dermatol 1960;82: $903-907$

10. Samuels MJ. Toxic epidermal necrolysis: a report of 42 cases. Br J Dermatol 1967; 79 : 672-677.

11. Tyson RG. Ushinski SC. Kisilevsky R. Toxic epidermal necrolysis (the scalded skin syndrome). Am $J$ Dis Child $1966 ; 111: 386-392$

12. Barrow GI. Clinical and bacteriological aspects of impetigo contagiosa. J $\mathrm{Hvg} 1955 ; 53$ : 495-508

13. Gillespie WA, Pope RC, Simpson K. Pemphigus neonatorum caused by Staphlococcus aureus type 71. BMJ 1957; 1: $1044-1046$.

14. Miller AA. An outbreak of pemphigus neonatorum in the maternity department of a general hospital: with special reference to the source of infection. J Obstet Gynaecol 1950 57: $415-422$

15. Parker MT. Tomlinson AJH, Williams REO. Impetigo contagiosa: the association of certain types of Staphy ococcus aureus and of Streptococcus pyogenes with superficial skin infections. $J$ Hyg 1955; 53: 458473 .

16. Parker MT, Williams REO. Further observations on the bacteriology of impetigo and pemphigus neonatorum. Acta Paediatr 1961; 50: 101-112.

17. Spittlehouse KE. Phage-types of Staphylococcus pyogenes isolated from impetigo and sycosis barbae. Lancet 1955:2: 378.

18. Parker MT. Some cultural characteristics of Staphylococcus aureus strains from superficial skin infections. $J \mathrm{Hyg} 1958$ 56: $238-253$.

19. Arbuthnott JP, Gemmell CG, Kent J, Lyell A. Haemolysin and enzyme patterns of coagulase-positive staphylococci isolated from toxic epidermal necrolysis, Ritter's disease and impetigo contagiosa. $J$ Med Microbiol 1969: 2 $479-487$.

20. Tait SC. The hydrolysis of lipids and esters by Staphylococcus aureus. D. Phil. Thesis. Paisley College of Technology, 1973.

21. Marples MJ. The ecology of the human skin. Springfield. IL C. C. Thomas. 1965.

22. Arbuthnott JP. Kent J. Lyell A, Gemmell CG. Toxic epidermal necrolysis produced an extracellular product of Staphylococcus aureus. Br J Dermatol 1971: 85: 145-149.

23. Melish ME. Glasgow LA. The staphylococcal scalded-skin syndrome. $N$ Engl J Med 1969; 282: 1114-1119.

24. Lyell A. Toxic epidermal necrolysis: the scalded skin syndrome. $J$ Clin Exp Dermatol November 1978; 15-31.

25. Melish ME. Glasgow LA. Staphylococcal scalded skin syn- that the age difference in susceptibility to ET in mice may also be relevant in man. The neonatal mouse model remains one of the most sensitive assays for ET activity in strains of $S$. aureus. drome: the expanded clinical syndrome. $J$ Pediatr 1971; 78: $958-967$.

26. Lyell A. Review of toxic epidermal necrolysis in Great Britain. Br J Dermatol 1967; 79: 662-671.

27. Rasmussen JE. Toxic epidermal necrolysis: a review of 75 cases in children. Arch Dermatol 1975; 111 : 1135-1139.

28. O'Keefe R, Dagg JH, MacKie RM. The staphylococcal scalded skin syndrome in two elderly immunocompromised patients. $B M J 1987 ; 295$ : 179-180.

29. Opal SM, Johnson-Winegar AD, Cross AS. Staphylococca scalded skin syndrome in two immunocompetent adults caused by exfoliatin B-producing Staphylococcus aureus. $J$ Clin Microbiol 1988; 26: 1283-1286.

30. Goldberg NS, Ahmed T, Robinson B, Ascensao J, Horowitz H Staphylococcal scalded skin syndrome mimicking acute graft-vs-host disease in a bone marrow transplant recipient. Arch Dermatol 1989; 125: 85-87.

31. Richard M, Mathieu-Serra A. Staphylococcal scalded skin syndrome in a homosexual adult. $J$ Am Acad Dermato $1986 ; 15,385-389$

32. Alcalay J, David M, Sandbank M. Bullous impetigo and localized scalded skin syndrome in the elderly. Israel $J \mathrm{Med}$ Sci 1987; 23 : 300-301.

33. Takiuchi I, Sasaki H, Takagi H. Higuchi D. Staphylococcal scalded skin syndrome in an adult. J Dermatol 1986; 13: 372-376.

34. Petzelbauer P, Konrad K, Wolff K. Staphylococcal scalded skin syndrome in two adults with acute kidney failure. Hautarzt 1989; 40: 90-93 (in German).

35. Saiag P, Caumes E, Roujean JC, Wechsler J, Touraine R. Staphylococcal scalded skin syndrome (staphylococcal Lyell's syndrome) in adults : 2 cases. Ann Dermatol Venereol 1988; 155: 1164-1166.

36. Khuong MA, Chosidow O, El-Solh $\mathrm{N}$ et al. Staphylococcal scalded skin syndrome in an adult: possible influence of non-steroidal anti-inflammatory drugs. Dermatologica 1993; 186: 153-1 54

37. Borchers SL, Gomez EC, Isseroff RR. Generalized staphylococcal scalded skin syndrome in an anephric boy undergoing hemodialysis. Arch Dermatol 1984; 120 : 912-918.

38. Donohue D, Robinson B, Goldberg NS. Staphylococcal scalded skin syndrome in a woman with chronic renal failure exposed to human immunodeficiency virus. Cutis $1991 ; 47$ 317-318.

39. Elsner P, Hartmann AA. Epidemiology of ETA- and ETBproducing staphylococci in dermatological patients Zentralbl Bakteriol Mikrobiol Hyg A 1988; 268: 534.

40. de Azevedo J, Arbuthnott JP. Prevalence of epidermolytic toxin in clinical isolates of Staphylococcus aureus. J Med Microbiol 1981; 14: 341-344.

41. Kondo I, Sakurai S, Sarai Y, Futaki S. Two serotypes of exfoliatin and their distribution in staphylococcal strains isolated from patients with scalded skin syndrome. $J$ Clin Microbiol 1975; 1: 397-400.

42. Dancer SJ, Poston SM, East J, Simmons NA, Noble WC. An outbreak of pemphigus neonatorum. $J$ Infect 1990; 20: $73-82$.

43. Dave J, Reith S, Nash JQ, Marples RR, Dulake C. A double outbreak of exfoliative toxin-producing strains of Staphylococcus aureus in a maternity unit. Epidemiol Infect 1994 112: $103-114$

44. Wiley BB, Glasgow LA, Rogolsky M. Staphylococcal scaldedskin syndrome: development of a primary binding assay for human antibody to the exfoliative toxin. Infect Immun 1976:13: $513-520$.

45. Lee CY, Schmidt JJ, Johnson-Winegar AD, Spero L, Iandolo JJ. Sequence determination and comparison of exfoliative toxin A and B genes from Staphylococcus aureus. Bacteriol 1987; 169: 3904-3909.

46. O'Toole PW, Foster TJ. Nucleotide sequence of the epidermo- 
lytic toxin A gene of Staphylococcus aureus. J Bacteriol 1987; 169: 3910-3915.

47. Sakurai S, Suzuki H, Kondo I. Cloning of the gene coding for staphylococcal exfoliative toxin $\mathrm{A}$ and its expression in Escherichia coli. FEMS Microbiol Lett 1987; 42: 63-67.

48. Rogolsky M, Wiley BB, Glasgow LA. Phage group II staphylococcal strains with chromosomal and extra-chromosoma genes for exfoliative toxin production. Infect Immun 1976; 13: 44-52.

49. Wiley BB, Rogolsky M. Molecular and serological differentiation of staphylococcal exfoliative toxin synthesized under chromosomal and plasmid control. Infect Immun 1977; 18: 487-494.

50. McLay ALC, Arbuthnott JP, Lyell A. Action of staphylococcal epidermolytic toxin on mouse skin: an electron microscopic study. J Invest Dermatol $1975 ; 65$ : 423-428.

51. Lillibridge CB, Melish ME, Glasgow LA. Site of action of exfoliative toxin in the staphylococcal scalded-skin syndrome. Pediatrics 1972; 50: 728-738.

52. Wuepper KD, Dimond RL, Knutson DD. Studies of the mechanism of epidermal injury by a staphylococcal epidermolytic toxin. J Invest Dermatol 1975; 65: 191-200.

53. Elias PM, Fritsch P, Epstein EH. Staphylococcal scalded skin syndrome. Clinical features, pathogenesis, and recent microbiological and biochemical developments. Arch Dermatol 1977; 113: 207-219.

54. Nishioka K, Katayama I, Sano S. Possible binding of epidermolytic toxin to a subcellular fraction of the epidermis. J Dermatol 1981; 8: 7-12.

55. Takiuchi I, Kawamura M, Teramoto T, Higuchi D. Staphylococcal exfoliative toxin induces caseinolytic activity. $J$ Infect Dis 1987; 156: 508-509.

56. Bailey CJ, de Azavedo J, Arbuthnott JP. A comparative study of two serotypes of epidermolytic toxin from Staphylococcus aureus. Biochim Biophys Acta 1980; 624: 111-120.

57. Kondo I, Sakurai S, Sarai Y. New type of exfoliatin obtained from staphylococcal strains, belonging to phage groups other than group II, isolated from patients with impetigo and Ritter's disease. Infect Immun 1974; 10: 851-861.

58. Sakurai S, Suzuki H, Kondo I. DNA sequencing of the eta gene coding for staphylococcal exfoliative toxin serotype A. $J$ Gen Microbiol 1988; 134: 711-717.

59. Bailey CJ, Smith TP. The reactive serine residue of epidermolytic toxin A. Biochem $J 1990 ; 269$ : 535-537.

60. Dancer SJ, Garratt R, Saldanha J, Jhoti H, Evans R. The epidermolytic toxins are serine proteases. FEBS Lett 1990 268: 129-132.

61. Prévost G, Rifai S, Chaix ML, Piémont Y. Functional evidence that the ser-195 residue of staphylococcal exfoliative toxin A is essential for biological activity. Infect Immun 1991 ; 59: 3337-3339.

62. Smith TP, Bailey CJ. Activity requirements of epidermolytic toxin from Staphylococcus aureus studied by an in vitro assay. Toxicon $1990 ; 28: 675-683$.

63. Rogolsky M, Wiley BB, Keyhari M, Glasgow LA. Interaction of staphylococcal exfoliative toxin with concanavalin A. Infect Immun 1974; 10: 1260-1265.

64. Kondo I, Sakurai S. Research on the receptor for staphylococcal exfoliatin. In: Jeljaszewicz J (ed) Staphylococci and staphylococcal infections. Proceedings of the IV International Symposium on Staphylococci and Staphylococcal Infections, Warszawa, Oct. 1979. Stuttgart, Gustav Fischer Verlag. 1981: 711-716.

65. Marrack P, Kappler J. The staphylococcal enterotoxins and their relatives. Science 1990; 248: 705-711.

66. Choi Y, Herman A, DiGiusto D, Wade T, Marrack P, Kappler $\mathrm{J}$. Residues of the variable region of the T-cell-receptor beta-chain that interact with $S$. aureus toxin superantigens. Nature 1990; 346: 471-473.

67. Rogolsky M, Warren R, Wiley BB, Nakamura HT, Glasgow LA. Nature of the genetic determinant controlling exfoliative toxin production in Staphylococcus aureus. J Bacteriol 1974; 117: 157-165

68. Arbuthnott JP. Characterisation of epidermolytic toxins of Staphylococcus aureus. In: Smith G, Macdonald A (eds) The staphylococci. Proceedings of the Alexander Ogston Centennial Conference. Aberdeen, Aberdeen University Press. 1981: 109-118.

69. Melish ME, Chen FS, Sprouse S, Stuckey M, Murata MS. Epidermolytic toxin in staphylococcal infection: toxin levels and host response. Zentralbl Bakteriol Suppl 1981; 10: $287-298$.

70. Haas Baker D, Wuepper KD, Rasmussen JE. Staphylococcal scalded skin syndrome: detection of antibody to epidermolytic toxin by a primary binding assay. Clin Exp Dermatol $1978 ; 3: 17-24$.

71. Wiley B, Glasgow L, Rogolsky M. Studies on staphylococcal scalded skin syndrome (SSSS): isolation and purification of toxin and development of a radio-immunobinding assay for antibodies to exfoliative toxin (ET). In: Jeljaszewicz J (ed) Staphylococci and staphylococcal diseases. Proceedings of III International Conference on Staphylococci and Staphylococcal Infections, Warszawa, Sept. 1975. Stuttgart, Gustav Fischer Verlag. 1976: 499-516.

72. Machida K, Sakurai S, Kondo I, Ikawa S. Genetic control of immune response to staphylococcal exfoliative toxin A in mice. Infect Immun 1987; 55: 2768-2773.

73. Elias PM, Fritsch P, Tappeiner G, Mittermayer H, Wolff K. Experimental staphylococcal toxic epidermal necrolysis (TEN) in adult humans and mice. J Lab Clin Med 1974;84: $414-424$

74. Kondo I, Sakurai S. Studies on toxicity and immunogenicity of staphylococcal exfoliatins A and B. In: Eaker D, Wadstrom T (eds) Natural toxins. Proceedings of the 6th International Symposium on animal, plant, and microbial toxins, Uppsala, Aug. 1979. New York, Pergamon. 1980: 379-387.

75. Arbuthnott JP, Billcliffe B, Thompson WD. Isoelectric focusing studies of staphylococcal epidermolytic toxin. FEBS Lett 1974; 46: 92-95.

76. Arbuthnott JP, Kent J, Lyell A, Gemmell CG. Studies of staphylococcal toxins in relation to toxic epidermal necrolysis (the scalded skin syndrome). Br J Dermatol 1972; 86 Suppl. 8: 35-39.

77. Kapral FA, Miller MM. A product of Staphylococcus aureus responsible for the scalded-skin syndrome. Bacteriol Proc $1971 ; 81$ (abstract). 